IRA-International Journal of Education \& Multidisciplinary Studies

ISSN 2455-2526; Vol.03, Issue 03 (2016)

Institute of Research Advances

http://research-advances.org/index.php/IJEMS

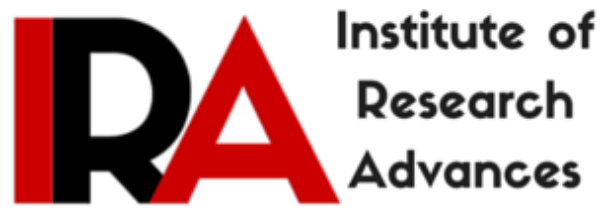

\title{
Being an Educator in Private vs. Public School System: A Comparative Study on Job Contentment
}

\author{
${ }^{1}$ Dr. Guru Tej S, \\ Associate Professor, Bangalore, India. \\ ${ }^{2}$ Dr. Priya Jindal, \\ Assistant Professor, Ambala, India. \\ ${ }^{3}$ Dr. Francisca Tej, \\ Associate Professor, Bangalore, India.
}

DOI: http://dx.doi.org/10.21013/jems.v3.n3.p4

\section{How to cite this paper:}

Tej S, D., Jindal, D., \& Tej, D. (2016). Being an Educator in Private vs. Public School System: A Comparative Study on Job Contentment. IRA International Journal of Education and Multidisciplinary Studies (ISSN 2455-2526), 3(3). doi:http://dx.doi.org/10.21013/jems.v3.n3.p4

(C) Institute of Research Advances

(cc) EY-NC

This works is licensed under a Creative Commons Attribution-Non Commercial 4.0 International License subject to proper citation to the publication source of the work.

Disclaimer: The scholarly papers as reviewed and published by the Institute of Research Advances (IRA) are the views and opinions of their respective authors and are not the views or opinions of the IRA. The IRA disclaims of any harm or loss caused due to the published content to any party. 


ABSTRACT
Job satisfaction can be defined as an extent of positive feelings or attitude that
individuals have towards their jobs. When a person says that he has high job
satisfaction, it means that he really likes his job, feels good about it and values his job
dignity. Job satisfaction is important technique used to motivate the employees to work
harder. It is often said that "a happy employee is a productive employee". Satisfied
employees work in integrity with organizational goals and their work performance
falls in sync with what is being expected of them. Satisfied employees stay happy,
hardworking, enthusiastic, committed and always open for new challenges. The
present study makes an effort to study the job satisfaction level among educators of
selected private and government school educator in Bangalore City. The paper also
investigates various factors influencing job satisfaction of educators. Based on the
survey, the paper attempts to gain insights into the satisfaction level from educators of
both types of schools. Some of the factors considered under this study are; current job
role, job satisfaction, salary earned, recognition at work, freedom at work,
accessibility to knowledge, facilities provided at work, and behavior of
colleagues/coworkers.

Key words: job satisfaction, educator, private school, government school

\section{Introduction}

Determined and passionate educator is the cornerstone of any education system. Happy and content educators bring quality into education and they remain as role models for students, whom students refer to, at every stage of life. Determination, quality and good attitude towards educating students comes not only from individualistic aspects which are imbibed within rather these depend upon the work environment, educational policies, educations system and reforms, educational leadership etc. There is another prominent factor that makes educator to perform their best and make $100 \%$ committed for work is job contentment.

Most of the times, satisfaction is confused with contentment. The Oxford dictionary defines satisfaction as "the fulfillment or gratification of a desire, need, or appetite." It defines contentment as "satisfied with things as they are." Being content is far more actualized and feeling of permanent than satisfaction, which mostly is temporary

Contentment with teaching as a career is an important policy issue since it is associated with teacher effectiveness which ultimately affects student achievement (Ashton and Webb, 1986; Carnegie Task Force on Teaching, 1986). Educators being the knowledge resources are the most important assets for any academic institution and for a successful education system to flourish, educators who are content with their job and work environment are most essential.

Job contentment among educators is a great need of the day, in developing today's generation, who will be tomorrow's prominent citizens. This study is an effort to understand the level of job contentment among educators in private and public school system.

The objectives of this paper are;

1. To compare the job satisfaction level of private and public school educators working in various schools of Bangalore city.

2. To identify the factors influencing the job satisfaction of educators working in Schools.

3. To analyze the relationship between socio-economic variables and job contentment of employees in the selected schools in Bangalore Region. 
4. To suggest strategies for better educator job contentment on the basis of research findings.

\section{Literature Review:}

\section{Job Contentment:}

Contentment on job is an affective reaction to an individual's work situation. It can be understood as a feeling about one's job, autonomy, pay, career growth opportunities, work environment, educational leadership, and interpersonal relationships in the institution. An educator with right elements of contentment would continue working for the same institution for a longer period and serve as a role model for the students. Highly content educator would live what he preaches/teaches and also less likely to be withdrawn from their responsibilities and activities of the school. This encourages students to find reliability and develop trust in such educator. On the other hand, a covetous educator would always feel insecure at the work place, mostly withdrawn from academic activities and will be obsessed with looking for other opportunities. This would take away educator's commitment, and also may make an educator to think of changing his profession too bringing imbalance in his performance and as a result student output being affected negatively.

Basu (2009) studied job satisfaction and mental health among teachers: A survey. He found that job satisfaction does have a significant relationship with mental health in case of primary school teachers. When gender, marital status and locality of the primary school teachers were taken into consideration, satisfied teachers evinced significantly better mental health than their unsatisfied counterparts.

(Singh, 2012) Conducted a study on the secondary school teachers from colleges affiliated to Punjab University to study the correlation between educators job satisfaction with their attitude towards teaching. The researcher also conducted a comparative study to analyze the male and female teacher job satisfaction with their attitude towards teaching. From the study it was revealed that there is no correlation between job satisfaction and attitude towards teaching.

(Ghosh, 2013) The study was aimed at highlighting the job satisfaction of teachers working at the primary school in relation to nature of job, gender, locale, management and educational qualification. Ghosh administered Dixit's job satisfaction scale (1998), developed by Panda (2007) over a sample of 100 primary school teachers of Dakshin Dinajpur district of West Bengal. The findings of the study revealed that female, public school and under graduate teachers are more satisfied on their job than the regular, male, private school and graduate teachers.

(Raj \& Lalitha, 2013) The researchers investigated the present level of job satisfaction among the private and public school teachers. In this research, 50 public and 50 Private teachers, 100 in total, working in different public and private schools were examined. The study revealed that there is no significant difference in the level of satisfaction of male and female teachers. Furthermore, it was again revealed that there is no significant difference in the level of satisfaction of Public and Private school teachers.

(Desta, 2014) Conducted a study to investigate relations of teachers' job satisfactions and commitment in selected general secondary schools of Hadiya Zone. Hence, it examined internal and external factors of teachers' job satisfaction as well as, the levels of teachers' commitments in the selected general secondary schools. To accomplish this purpose, the study employed a concurrent nested research design. A total of 159 individuals have participated in the study. Higher levels of teachers' job satisfaction were associated with higher levels commitment. It was also found out that external 
factors have more influence than internal factor on teachers' job satisfaction in the study area. External factors were providing necessary equipment and material for schools, fair incentives and benefit for teachers, access of transportation, furnishing the working conditions with refreshment facilities etc.

\section{Methodology and Procedure:}

The main aim of this study was to measure the level of job satisfaction among educators of private and public schools belonging to Bangalore City.

Sample: The sample was drawn from private and public schools from across Bangalore City randomly. A total of 80 educators teaching at private and public schools were selected as respondents; 40 respondents from private schools and 40 from government schools.

Data Collection: Data collection was through primary data. All the data collected for the study was from the questionnaires filled and approved by respective educators as respondents.

Primary data: All primary data required for the study has been collected with the help of questionnaires, personal interview, informal discussion with educators of both type of schools.

Statistical techniques: Mean, standard deviation and independent sample t-test have been used to analyze the data.

\section{Data analysis and interpretation}

\subsection{Overall job contentment of Private and Government school Educators}

Table 1.1 Group Statistics

\begin{tabular}{|l|l|r|r|r|r|}
\hline & School Type & N & Mean & \multicolumn{1}{c|}{$\begin{array}{c}\text { Std. } \\
\text { Deviation }\end{array}$} & $\begin{array}{c}\text { Std. Error } \\
\text { Mean }\end{array}$ \\
\hline $\begin{array}{l}\text { Contentment Level } \\
\text { with respect to } \\
\text { current job }\end{array}$ & Private School & 40 & 2.53 & 1.377 & .218 \\
& Public School & 40 & 2.70 & 1.324 & .209 \\
\hline
\end{tabular}

Table 1.2 Independent Samples Test

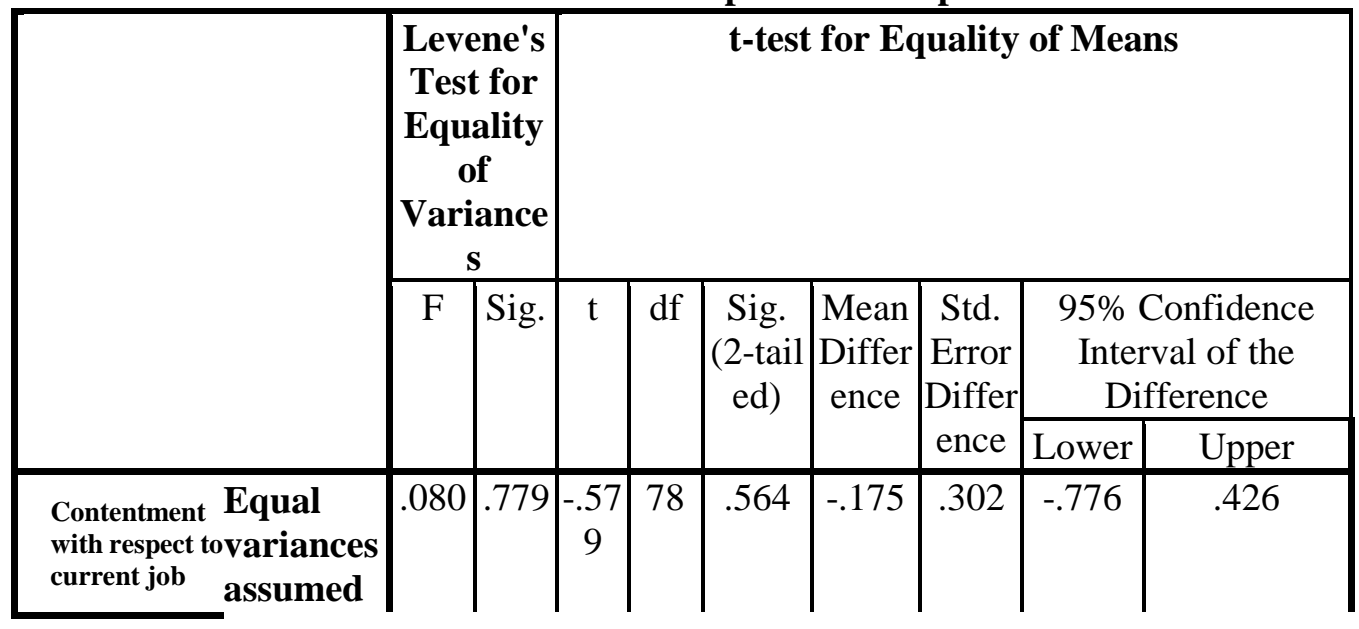




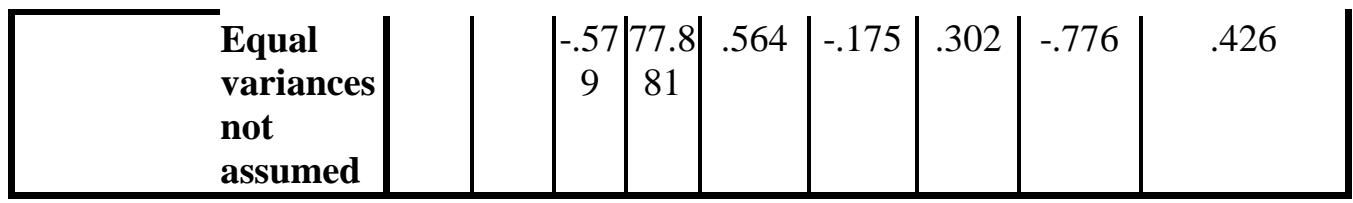

Though remuneration is essential for employees, one cannot say that remuneration is everything. For many employees' job responsibilities, work culture, institutional policies etc. are also important in taking up a job and committing to a role. Educators from private and public schools were interviewed to study how satisfied they are with respect to the assigned job. As a response, table $1.1 \& 1.2$ displays that there is no significant difference between private school educators and Government school educators with respect to their current job.

\subsection{Contentment with respect to Salary earned}

Table 2.1 Group Statistics

\begin{tabular}{|l|l|r|r|r|c|}
\hline & School Type & N & Mean & $\begin{array}{c}\text { Std. } \\
\text { Deviation }\end{array}$ & $\begin{array}{c}\text { Std. Error } \\
\text { Mean }\end{array}$ \\
\hline Contentment with & Private School & 40 & 2.05 & 1.616 & .256 \\
Salary earned & Public School & 40 & 3.05 & 1.568 & .248 \\
\hline
\end{tabular}

Table 2.2 Independent Samples Test

\begin{tabular}{|c|c|c|c|c|c|c|c|c|c|c|}
\hline & \multicolumn{2}{|c|}{$\begin{array}{c}\text { Levene's } \\
\text { Test for } \\
\text { Equality } \\
\text { of } \\
\text { Variances }\end{array}$} & \multicolumn{7}{|c|}{ t-test for Equality of Means } \\
\hline & & \multirow[t]{2}{*}{$\mathrm{F}$} & \multirow[t]{2}{*}{ Sig. } & \multirow[t]{2}{*}{$\mathrm{t}$} & \multirow[t]{2}{*}{$\mathrm{df}$} & \multirow[t]{2}{*}{$\begin{array}{l}\text { Sig. } \\
\text { (2-tai } \\
\text { led) }\end{array}$} & \multirow[t]{2}{*}{$\begin{array}{l}\text { Mean } \\
\text { Differ } \\
\text { ence }\end{array}$} & \multirow{2}{*}{$\begin{array}{c}\text { Std. } \\
\text { Error } \\
\text { Differen } \\
\text { ce }\end{array}$} & \multicolumn{2}{|c|}{$\begin{array}{l}\text { 95\% Confidence } \\
\text { Interval of the } \\
\text { Difference }\end{array}$} \\
\hline & & & & & & & & & Lower & Upper \\
\hline $\begin{array}{l}\text { Contentment } \\
\text { with Salary } \\
\text { earned }\end{array}$ & $\begin{array}{l}\text { Equal } \\
\text { variances } \\
\text { assumed } \\
\text { Equal } \\
\text { variances } \\
\text { not assumed }\end{array}$ & $\begin{array}{r}.03 \\
6\end{array}$ & 851 & $\begin{array}{r}-2.80 \\
8 \\
-2.80 \\
8\end{array}$ & $\begin{array}{r}78 \\
\\
77.92 \\
8\end{array}$ & $\begin{array}{l}.006 \\
.006\end{array}$ & $\begin{array}{l}-1.000 \\
-1.000\end{array}$ & .356 & -1.709 & -.291 \\
\hline
\end{tabular}

Salary is a reward that employees get for their contribution. This reward is a fundamental factor in motivating employees to perform their best. Though there are n-number of monetary and non-monetary rewards which employers consider, salary is the very essential factor that any employee would expect in return to his performance. So the respondents from private and public schools were surveyed to study how satisfied they are with the salary that they are being offered. As a response, table $2.1 \& 2.2$ revealed that there is a significant difference between satisfaction level with respect to salary among educators from private and public schools. Hence it was inferred that government school educators are significantly more content than private school educators as they feel they are paid according to their educational qualification and experience. 


\subsection{Contentment with respect to Job Security}

Table 3.1 Group Statistics

\begin{tabular}{|l|l|r|r|r|r|}
\hline & School Type & N & Mean & Std. Deviation & $\begin{array}{c}\text { Std. Error } \\
\text { Mean }\end{array}$ \\
\hline Contentment with Job & Private School & 40 & 2.23 & 1.577 & .249 \\
Security & Public School & 40 & 3.20 & 1.636 & .259 \\
\hline
\end{tabular}

Table 3.2 Independent Samples Test

\begin{tabular}{|c|c|c|c|c|c|c|c|c|c|c|}
\hline & \multicolumn{2}{|c|}{$\begin{array}{c}\text { Levene's } \\
\text { Test for } \\
\text { Equality of } \\
\text { Variances } \\
\end{array}$} & \multicolumn{7}{|c|}{ t-test for Equality of Means } \\
\hline & & \multirow[t]{2}{*}{$\mathrm{F}$} & \multirow[t]{2}{*}{ Sig. } & \multirow[t]{2}{*}{$\mathrm{t}$} & \multirow[t]{2}{*}{$\mathrm{df}$} & \multirow[t]{2}{*}{$\begin{array}{l}\text { Sig. } \\
\text { (2-taile } \\
\text { d) }\end{array}$} & \multirow[t]{2}{*}{$\begin{array}{c}\text { Mean } \\
\text { Differen } \\
\text { ce }\end{array}$} & \multirow[t]{2}{*}{$\begin{array}{c}\text { Std. } \\
\text { Error } \\
\text { Differen } \\
\text { ce }\end{array}$} & \multicolumn{2}{|c|}{$\begin{array}{c}95 \% \\
\text { Confidence } \\
\text { Interval of the } \\
\text { Difference }\end{array}$} \\
\hline & & & & & & & & & Lower & $\begin{array}{c}\text { Upp } \\
\text { er }\end{array}$ \\
\hline $\begin{array}{l}\text { Contentment } \\
\text { with Job } \\
\text { Security }\end{array}$ & $\begin{array}{l}\text { Equal } \\
\text { variances } \\
\text { assumed } \\
\text { Equal } \\
\text { variances not } \\
\text { assumed }\end{array}$ & .190 & .664 & $\begin{array}{r}-2.71 \\
4 \\
-2.71 \\
4\end{array}$ & $\begin{array}{r}77.89 \\
4\end{array}$ & .008 & -.975 & .359 & $\begin{array}{l}-1.690 \\
-1.690\end{array}$ & $\begin{array}{r}-.26 \\
0 \\
-.26 \\
0\end{array}$ \\
\hline
\end{tabular}

Job security has significant impact on employees. Job security creates a sense of belongingness and an employee who feels that his job is secured would work in-sync with institutional goals and would never be in search of opportunities outside. To study the job security of educators at private and public schools, the respondents were asked how satisfied they are with the level of job security in their respective schools. As a response, table $3.1 \& 3.2$ displays that the equal variance is assumed. It could be inferred that the level of job security among private school and public school educators is significantly different. It was also observed that public school educators enjoy more job security than educators employed in private schools.

\subsection{Contentment with respect to Recognition at Work}

Table 4.1 Group Statistics

\begin{tabular}{|l|l|r|r|r|r|}
\hline & School Type & N & Mean & \multicolumn{1}{c|}{$\begin{array}{c}\text { Std. } \\
\text { Deviation }\end{array}$} & $\begin{array}{c}\text { Std. Error } \\
\text { Mean }\end{array}$ \\
\hline Contentment with & Private School & 40 & 3.55 & 1.280 & .202 \\
recognition at work & Public School & 40 & 3.08 & 1.366 & .216 \\
\hline
\end{tabular}


Table 4.2 Independent Samples Test

\begin{tabular}{|c|c|c|c|c|c|c|c|c|c|c|}
\hline & \multicolumn{2}{|c|}{$\begin{array}{c}\text { Levene's } \\
\text { Test for } \\
\text { Equality of } \\
\text { Variances } \\
\end{array}$} & \multicolumn{7}{|c|}{ t-test for Equality of Means } \\
\hline & & \multirow[t]{2}{*}{$\mathrm{F}$} & \multirow[t]{2}{*}{ Sig. } & \multirow[t]{2}{*}{$\mathrm{t}$} & \multirow[t]{2}{*}{$\mathrm{df}$} & \multirow[t]{2}{*}{$\begin{array}{l}\text { Sig. } \\
\text { (2-taile } \\
\text { d) }\end{array}$} & \multirow[t]{2}{*}{$\begin{array}{c}\text { Mean } \\
\text { Differen } \\
\text { ce }\end{array}$} & \multirow[t]{2}{*}{$\begin{array}{c}\text { Std. } \\
\text { Error } \\
\text { Differen } \\
\text { ce }\end{array}$} & \multicolumn{2}{|c|}{$\begin{array}{c}95 \% \\
\text { Confidence } \\
\text { Interval of the } \\
\text { Difference }\end{array}$} \\
\hline & & & & & & & & & Lower & Upper \\
\hline $\begin{array}{l}\text { Contentment } \\
\text { with }\end{array}$ & $\begin{array}{l}\text { Equal } \\
\text { variances } \\
\text { assumed }\end{array}$ & .121 & .729 & 1.605 & 78 & .113 & .475 & .296 & -.114 & 1.064 \\
\hline $\begin{array}{l}\text { recognition at } \\
\text { work }\end{array}$ & $\begin{array}{l}\text { Equal } \\
\text { variances } \\
\text { not assumed }\end{array}$ & & & 1.605 & $\begin{array}{r}77.6 \\
72\end{array}$ & .113 & .475 & .296 & -.114 & 1.064 \\
\hline
\end{tabular}

Recognition refers to appreciation or acknowledgement of employees work. It is most obvious; educators would look for recognition for their contribution at work by their superior/educational leaders. Establishing identity or recognition at work would add on to job contentment at the workplace. Respondents were asked if they are content with the recognition they receive at work from their supervisors. In response, table $4.1 \& 4.2$ displays that the variability in two conditions is same and hence it is inferred that the amount of contentment with respect to recognition at work is significantly the same among public and private school educators.

\subsection{Contentment with respect to Accessibility to knowledge}

Table 5. 1 Group Statistics

\begin{tabular}{|l|l|r|r|r|r|}
\hline & School Type & \multicolumn{1}{|c|}{ N } & \multicolumn{1}{c|}{ Mean } & \multicolumn{1}{c|}{$\begin{array}{c}\text { Std. } \\
\text { Deviation }\end{array}$} & \multicolumn{1}{c|}{$\begin{array}{c}\text { Std. Error } \\
\text { Mean }\end{array}$} \\
\hline $\begin{array}{ll}\text { Contentment with } \\
\text { Accessibility to }\end{array}$ & Private School & 40 & 2.98 & 1.368 & .216 \\
knowledge & Public School & 40 & 3.45 & 1.319 & .209 \\
\hline
\end{tabular}

Table 5.2 Independent Samples Test

\begin{tabular}{|c|c|c|c|c|c|c|c|c|c|c|}
\hline & \multicolumn{2}{|c|}{$\begin{array}{c}\text { Levene's } \\
\text { Test for } \\
\text { Equality } \\
\text { of } \\
\text { Variances } \\
\end{array}$} & \multicolumn{7}{|c|}{ t-test for Equality of Means } \\
\hline & & \multirow[t]{2}{*}{$\mathrm{F}$} & \multirow[t]{2}{*}{ Sig. } & \multirow[t]{2}{*}{$\mathrm{t}$} & \multirow[t]{2}{*}{$\mathrm{df}$} & \multirow[t]{2}{*}{$\begin{array}{l}\text { Sig. } \\
\text { (2-taile } \\
\text { d) }\end{array}$} & \multirow{2}{*}{\begin{tabular}{|c|} 
Mea \\
$n$ \\
Diffe \\
rence
\end{tabular}} & \multirow{2}{*}{$\begin{array}{c}\text { Std. } \\
\text { Error } \\
\text { Differen } \\
\text { ce }\end{array}$} & \multicolumn{2}{|c|}{$\begin{array}{l}\text { 95\% Confidence } \\
\text { Interval of the } \\
\text { Difference }\end{array}$} \\
\hline & & & & & & & & & Lower & Upper \\
\hline $\begin{array}{l}\text { Contentment } \\
\text { with }\end{array}$ & $\begin{array}{l}\text { Equal } \\
\text { variances } \\
\text { assumed }\end{array}$ & .332 & $\begin{array}{r}.56 \\
6\end{array}$ & $\begin{array}{r}-1.58 \\
1\end{array}$ & 78 & .118 & -.475 & .301 & -1.073 & .123 \\
\hline $\begin{array}{l}\text { Accessibility to } \\
\text { knowledge }\end{array}$ & $\begin{array}{l}\text { Equal } \\
\text { variances } \\
\text { not assumed }\end{array}$ & & & $\begin{array}{r}-1.58 \\
1\end{array}$ & $\begin{array}{r}77.89 \\
9\end{array}$ & .118 & -.475 & .301 & -1.073 & .123 \\
\hline
\end{tabular}


The fundamental aim and aspiration of an educator would be to have continuous access to knowledge through various sources. It would be ideal when the school tries to provide facilities like library, online learning material, and provision to attend trainings, seminars etc. So the respondents were asked if they had contentment with respect to access to knowledge from their respective schools. In response, table $5.1 \&$ 5.2 displays that the variability is same and it is inferred that the amount of contentment with respect to recognition at work is significantly same among educators in both public and private schools.

\subsection{Contentment with respect to Freedom at Work}

Table 6.1 Group Statistics

\begin{tabular}{|l|l|r|r|r|r|}
\hline & School Type & N & Mean & \multicolumn{1}{c|}{$\begin{array}{c}\text { Std. } \\
\text { Deviation }\end{array}$} & \multicolumn{1}{c|}{$\begin{array}{c}\text { Std. Error } \\
\text { Mean }\end{array}$} \\
\hline $\begin{array}{l}\text { Contentment with } \\
\text { respect to Freedom at } \\
\text { work }\end{array}$ & Private School & 40 & 2.33 & 1.141 & .180 \\
& Public School & 40 & 3.23 & 1.097 & .174 \\
\hline
\end{tabular}

Table 6.2 Independent Samples Test

\begin{tabular}{|c|c|c|c|c|c|c|c|c|c|c|}
\hline & \multicolumn{2}{|c|}{$\begin{array}{c}\text { Levene's } \\
\text { Test for } \\
\text { Equality of } \\
\text { Variances }\end{array}$} & \multicolumn{7}{|c|}{ t-test for Equality of Means } \\
\hline & & \multirow[t]{2}{*}{$\mathrm{F}$} & \multirow[t]{2}{*}{ Sig. } & \multirow[t]{2}{*}{$\mathrm{T}$} & \multirow[t]{2}{*}{ df } & \multirow[t]{2}{*}{$\begin{array}{l}\text { Sig. } \\
\text { (2-tail } \\
\text { ed) }\end{array}$} & \multirow[t]{2}{*}{$\begin{array}{l}\text { Mean } \\
\text { Differ } \\
\text { ence }\end{array}$} & \multirow{2}{*}{$\begin{array}{c}\text { Std. } \\
\text { Error } \\
\text { Differe } \\
\text { nce }\end{array}$} & \multicolumn{2}{|c|}{$\begin{array}{l}\text { 95\% Confidence } \\
\text { Interval of the } \\
\text { Difference }\end{array}$} \\
\hline & & & & & & & & & Lower & Upper \\
\hline $\begin{array}{l}\text { Contentment } \\
\text { with respect to } \\
\text { Freedom at } \\
\text { work }\end{array}$ & $\begin{array}{l}\text { Equal } \\
\text { variances } \\
\text { assumed } \\
\text { Equal } \\
\text { variances } \\
\text { not assumed }\end{array}$ & .513 & .476 & $\begin{array}{r}-3.59 \\
5 \\
-3.59 \\
5\end{array}$ & $\begin{array}{r}77.8 \\
82\end{array}$ & .001 & -.900 & .250 & -1.398 & -.402 \\
\hline
\end{tabular}

When educators were surveyed, most of them said that they would just want their employers to trust in them and give enough mental space so that they can independently plan, coordinate and work. A continuous monitoring on an hourly or daily basis would more become a hindrance than positively promoting educators' productivity. Being able to develop sufficient trust between educator and the supervisor/educational leader and having enough freedom at work would lead towards job contentment.

So the respondents were asked if they were happy with respect to freedom at work in their respective schools. In response, table $6.1 \& 6.2$ displays that the variability in both the conditions is same. However it is concluded that the contentment with respect to freedom at work is significantly more among public school educators than educators in private school. 


\subsection{Contentment with respect to Facilities provided at Work}

Table 7. 1 Group Statistics

\begin{tabular}{|l|l|r|r|r|r|}
\hline & School Type & N & Mean & $\begin{array}{c}\text { Std. } \\
\text { Deviation }\end{array}$ & $\begin{array}{c}\text { Std. Error } \\
\text { Mean }\end{array}$ \\
\hline Contentment with & Private School & 40 & 3.40 & 1.128 & .178 \\
Facilities provided at work & Public School & 40 & 3.10 & 1.236 & .195 \\
\hline
\end{tabular}

Table 7. 2 Independent Samples Test

\begin{tabular}{|c|c|c|c|c|c|c|c|c|c|c|}
\hline & \multicolumn{2}{|c|}{$\begin{array}{l}\text { Levene's } \\
\text { Test for } \\
\text { Equality of } \\
\text { Variances }\end{array}$} & \multicolumn{7}{|c|}{ t-test for Equality of Means } \\
\hline & & \multirow[t]{2}{*}{$\mathrm{F}$} & \multirow[t]{2}{*}{ Sig. } & \multirow[t]{2}{*}{$\mathrm{T}$} & \multirow[t]{2}{*}{$\mathrm{df}$} & \multirow[t]{2}{*}{$\begin{array}{l}\text { Sig. } \\
\text { (2-taile } \\
\text { d) }\end{array}$} & \multirow{2}{*}{$\begin{array}{c}\text { Mea } \\
n \\
\text { Diff } \\
\text { eren } \\
\text { ce }\end{array}$} & \multirow{2}{*}{$\begin{array}{c}\text { Std. } \\
\text { Error } \\
\text { Differen } \\
\text { ce }\end{array}$} & \multicolumn{2}{|c|}{$\begin{array}{l}\text { 95\% Confidence } \\
\text { Interval of the } \\
\text { Difference }\end{array}$} \\
\hline & & & & & & & & & Lower & Upper \\
\hline $\begin{array}{l}\text { Contentment } \\
\text { with Facilities }\end{array}$ & $\begin{array}{l}\text { Equal } \\
\text { variances } \\
\text { assumed }\end{array}$ & .537 & .466 & $\begin{array}{r}1.13 \\
4\end{array}$ & 78 & .260 & .300 & .265 & -.227 & .827 \\
\hline $\begin{array}{l}\text { provided at } \\
\text { work }\end{array}$ & $\begin{array}{l}\text { Equal } \\
\text { variances not } \\
\text { assumed }\end{array}$ & & & $\begin{array}{r}1.13 \\
4\end{array}$ & $\begin{array}{r}77.3 \\
51\end{array}$ & .260 & .300 & .265 & -.227 & .827 \\
\hline
\end{tabular}

To run a school successfully, just a classroom is never sufficient. To make the learning effective educators would look for teaching/learning aids, good seating arrangements for students, computers, internet connectivity to remain connected with current affairs and to conduct more academic research, and also clean drinking water, good facility for lunch \& snacks etc. So the respondents were asked if they felt content with respect to facilities provided at work.

As opposed to general impression that public schools lack right amenities for good education, table $7.1 \& 7.2$ displays that the facilities provided at both private and public schools are almost same. Hence it is inferred that the amount of contentment with respect to facilities provided at work is almost the same among public schools and private schools.

\subsection{Contentment with respect to Behavior of Coworkers}

Table 8. 1 Group Statistics

\begin{tabular}{|l|l|r|r|r|r|}
\hline & School Type & N & Mean & \multicolumn{1}{c|}{$\begin{array}{c}\text { Std. } \\
\text { Deviation }\end{array}$} & \multicolumn{1}{c|}{$\begin{array}{c}\text { Std. Error } \\
\text { Mean }\end{array}$} \\
\hline $\begin{array}{l}\text { Contentment with } \\
\text { behavior of }\end{array}$ & Private School & 40 & 2.40 & 1.676 & .265 \\
Coworkers & Public School & 40 & 3.58 & 1.583 & .250 \\
\hline
\end{tabular}


Table 8.2 Independent Samples Test

\begin{tabular}{|c|c|c|c|c|c|c|c|c|c|c|}
\hline & \multicolumn{2}{|c|}{$\begin{array}{c}\text { Levene's } \\
\text { Test for } \\
\text { Equality of } \\
\text { Variances } \\
\end{array}$} & \multicolumn{7}{|c|}{ t-test for Equality of Means } \\
\hline & & \multirow[t]{2}{*}{$\mathrm{F}$} & \multirow[t]{2}{*}{ Sig. } & \multirow[t]{2}{*}{$\mathrm{t}$} & \multirow[t]{2}{*}{$\mathrm{df}$} & \multirow[t]{2}{*}{$\begin{array}{l}\text { Sig. } \\
\text { (2-taile } \\
\text { d) }\end{array}$} & \multirow[t]{2}{*}{$\begin{array}{c}\text { Mean } \\
\text { Differen } \\
\text { ce }\end{array}$} & \multirow[t]{2}{*}{$\begin{array}{c}\text { Std. } \\
\text { Error } \\
\text { Differen } \\
\text { ce }\end{array}$} & \multicolumn{2}{|c|}{$\begin{array}{c}95 \% \\
\text { Confidence } \\
\text { Interval of the } \\
\text { Difference } \\
\end{array}$} \\
\hline & & & & & & & & & Lower & $\begin{array}{c}\text { Uppe } \\
\text { r }\end{array}$ \\
\hline $\begin{array}{l}\text { Contentment } \\
\text { with behavior } \\
\text { of Coworkers }\end{array}$ & $\begin{array}{l}\text { Equal } \\
\text { variances } \\
\text { assumed } \\
\text { Equal } \\
\text { variances not } \\
\text { assumed }\end{array}$ & .115 & .736 & $\begin{array}{r}-3.22 \\
3 \\
-3.22 \\
3\end{array}$ & $\begin{array}{r}77.7 \\
47\end{array}$ & .002 & $\begin{array}{l}-1.175 \\
-1.175\end{array}$ & .365 & -1.901 & -.449 \\
\hline
\end{tabular}

The positive relationship between coworkers is one of the key factors that adds to the contentment and deriving a happy work place environment. When coworkers/colleagues are cooperative, there exists a healthy relationship, learning atmosphere, motivation and enthusiasm to attend work and discuss constructive ideas and teaching plans. The survey included an inquiry into understanding how content are educators with respect to colleagues/coworkers. From table $8.1 \& 8.2$ it is observed that, there is significant difference between satisfaction with behavior of coworkers among private and government school educators. The amount of satisfaction with respect to behavior of co-workers is more among public school educators compared to educators in private schools.

\section{FINDINGS and CONCLUSION}

1. Educators in public schools as compared to educators in private schools have more contentment with respect to their salary earned.

2. Respondents from public schools as compared to private school educators felt that they have job security.

3. Educators in public schools as compared to private schools agreed that they have cooperative coworkers/colleagues at work.

4. No significant difference was noticed with respect to public school educators as compared to private school educators in terms of their current job, recognition at work, accessibility to knowledge, freedom at work and facilities provided for educators.

5. The general impression among public that educators in public school system are not given enough facilities and not motivated enough is not seen to be true and may be deeper research to know more is needed due to the changing conditions in government run public school systems.

The overall study helped not only in understanding the above findings; rather it gave more insights into deeper aspects of educators' contentment on job. Educators aspire for respect, empowerment, training \& development, workshops in regular intervals, opportunities to interact with educators and policy makers from other schools whenever there is need for it, job security, appropriate task allotment, appreciation for the work done, timely promotions, educational leadership etc. Although few aspects like salary, job security, relationship with colleagues etc. are comparatively better in public schools, still there needs to be many more reforms and good practices 
implemented in both public and private schools. Government has formulated several useful policies like, pay at par with qualification and experience, more facilities for students \& teachers, student-teacher ratio, teacher trainings etc. But there exists a gap in putting these policies into practice. Government, educational leaders, policy makers, school authorities have to spend their quality time and effort in coming out with measures to enhance educator job contentment, as a happy educator can build a happy society around him. A good system can be achieved when educators are given opportunities to take part in decision making and their ideas are constructively appreciated. This way policy makers can also have insights into what is needed by educators and educators can feel empowered as well as included, boost up their morale and get involved in quality teaching-learning practices in grooming tomorrows' prominent citizens.

\section{References}

Basu, R. (2009). Job satisfaction and mental health among teachers: A survey Experiments in education, Vol.XXXVII (04)

Desta, A. (2014, June). Teachers' job satisfaction and commitment in general secondary schools of Hadiya. Hadiya, Ethiopia.

Ghosh, M. (2013). Job Satisfaction of teachers working at primary school. International Journal of Humanities and Social Science Invention, 01-05.

Raj, T., \& Lalitha. (2013). Job satisfaction among teachers of private and government schools: A Comparitive Analysis. International Journal of Social Science \& Interdisciplinary Research, 2 (9).

Singh, G. (2012). Job satisfaction of teacher educators in relation to their attitude towards teaching. E-journal of All India association for educational research. 